\title{
Application of dsRNA VP15-WSSV by Oral Vaccination to Increase Survival Rate and Response Immunes of Tiger Shrimp
} Penaeus monodon

Andi Parenrengi, Andi Tenriulo, Emma Suryati, Rosmiati Rosmiati, Samuel Lante, Andi Asmawati Azis ${ }^{1}$, Alimuddin Alimuddin ${ }^{2}$

10.18805/IJAR.BF-1460

\begin{abstract}
Background: RNA interference (RNAi) has recently introduced as a powerful technique for specific gene silencing in antiviral therapy for controlling shrimp diseases. The present study was conducted to assess the effect of dsRNA VP15-WSSV vaccine by oral administration on tiger shrimp survival rate and response immunes.

Methods: A gene encoding VP15 was isolated from tiger shrimp infected WSSV and cloned into the L4440 vector with the T7 promoter. For mass production, the pT7-VP15 gene construct was transformed to bacteria. The bacteria were inactivated using the heat-killed method by immersion and $10^{8}$ cells of bacteria were mixed with $0.02 \mathrm{~g}$ of commercial shrimp feed for dsRNA application. The shrimp were fed by: (A) feed containing dsRNA and coated by fish oil, (B) feed without dsRNA and coated by fish oil and (C) feed without dsRNA and fish oil. The shrimp were challenged with WSSV by intramuscular injection after vaccination for two weeks. The survival rate (SR) after the challenge test was counted daily, while the THC and proPO were observed before, then on $1^{\text {st }}, 3^{\text {rd }}$ and $5^{\text {th }}$ days post-challenge (dpc).

Result: The survival rate of tiger shrimp for all treatments tended to decrease until the $3^{\text {rd }} \mathrm{dpc}$, while the $4^{\text {th }} \mathrm{dpc}$ the vaccinated tiger shrimp was started to exhibit the higher SR compared to both treatments. The vaccinated tiger shrimp had significantly $(P<0.05)$ higher SR and THC compared with both control treatments, but not significantly $(P>0.05)$ for proPO activity. The results indicated that the application of oral dsRNA vaccination suggested increasing in SR and response immune of tiger shrimp.
\end{abstract}

Key words: dsRNA VP15 vaccine, Oral administration, Response immune, Survival rate, Tiger shrimp.

\section{INTRODUCTION}

White spot disease (WSD) is a serious viral disease caused by the white spot syndrome virus (WSSV) that infects many crustacean species, including the tiger shrimp Penaeus monodon. WSSV has been extensively studied since the WSD outbreak in shrimp aquaculture in 1990 (Feng et al., 2017; Uma et al., 2005). During WSSV infection, the interaction between cell surface protein receptors and viral proteins (VP) on target cells is the basic point of viral entry and replication (Kiataramgul et al., 2020). The virion nucleocapsid consists of three major proteins (VP15, VP24 and VP26) and the envelope contains two major proteins (VP19 and VP28), all of which play a key role in the systemic infection by WSSV (Van Hulten et al., 2001). The gene encoding VP15 has been identified and characterized by protein sequencing, in which the VP15 is located on the ORF109 and reported as a candidate DNA-binding protein in the nucleocapsid (Van Hulten et al., 2002).

Controlling WSSV on shrimp aquaculture has widely been the subject of several studies. However, there is no effective approach for controlling this viral disease. RNA interference (RNAi) is a relatively new technology that has the potential tool for silencing specific genes of WSSV and might provide a novel therapeutic strategy against virus infection in shrimp (Itsathitphaisarn et al., 2016; Reshi et al., 2014). Meanwhile, the application of RNAi technology for
Research Institute for Brackishwater Aquaculture and Fisheries Extension, Maros 90512, Indonesia.

${ }^{1}$ Department of Biology, State University of Makassar, Makassar 90222, Indonesia.

2Department of Aquaculture, IPB University, Bogor 16680, Indonesia.

Corresponding Author: Andi Parenrengi, Research Institute for Brackishwater Aquaculture and Fisheries Extension, Maros 90512, Indonesia. Email: andi_parenrengi@hotmail.com

How to cite this article: Parenrengi, A., Tenriulo, A., Suryati, E., Rosmiati, R., Lante, S., Azis, A.A. and Alimuddin, A. (2022). Application of dsRNA VP15-WSSV by Oral Vaccination to Increase Survival Rate and Response Immunes of Tiger Shrimp Penaeus monodon. Indian Journal of Animal Research. DOI: 10.18805/ IJAR.BF-1460.

Submitted: 30-10-2021 Accepted: 26-12-2021 Online: 29-01-2022

disease prevention in shrimp is still very limited. The focus of this present study was on the major structural proteins of VP15, which play an important role in the WSSV infection process in shrimp (Van Hulten et al., 2002).

The identification and characterization of the VP15 have been reported (Van Hulten et al., 2002; Witteveldt et al., 2005; Xing and Shi, 2011) and its applications have been demonstrated the potential way to use for protecting the viral shrimp diseases (Boonyakida et al., 2020). A gene encoding VP15 isolated from WSSV infected tiger shrimp 
in Indonesia has been identified and characterized by Parenrengi et al. (2017). The successful production by invitro using MEGAscript RNAi kit and in-vivo (Mulyaningrum et al., 2018; Parenrengi et al., 2018) has been proven led to apply in aquaculture for preventing the WSD. Application of dsRNA produced by in-vivo showed better survival and immune response than control shrimp for both the injection and the immersion method (Parenrengi et al., 2018, 2019). The vaccination by oral administration is expected to be an efficient way in mass application. The use of dsRNA by oral administration is required to provide a simple vaccination technique and the in-vivo dsRNA production is easier and can be carried out by mass production. The aim of this study was to assess the effect of dsRNA VP15-WSSV vaccine on the survival rate and immunological responses of tiger shrimp after oral vaccination.

\section{MATERIALS AND METHODS}

The study was carried out in a period of February-October 2019 at the Tiger Shrimp Breeding Station and Biotechnology Laboratory, Research Institute for Brackishwater Aquaculture and Fisheries Extension (RIBAFE), South Sulawesi, Indonesia. Cloning and constructing a gene pT7-VP15 were performed at Fish Reproduction and Genetics Laboratory, IPB University, Bogor, Indonesia.

\section{Preparing of dsRNA vaccine}

A gene encoding VP15 was isolated from tiger shrimp infected by WSSV and cloned into the $L 4440$ vector containing the T7 promoter. The pT7-VP15 gene construct was transformed to bacteria Escherichia coli $\mathrm{DH} 5 \alpha$ (Parenrengi et al., 2017). Bacteria were grown on liquid LB media in a $15 \mathrm{~mL}$ test tube and then incubated overnight at $37^{\circ} \mathrm{C}$ at a $120 \mathrm{rpm}$. Bacteria were harvested by centrifugation at 5,000 rpm for 5 minutes. The pellet form was used as a vaccine material and PCR template was used to verify the gene construct in bacterial plasmids using gene-specific primers, i.e: forward primer VP-15 F:5'-cgcggatccgatgacaa aataccccgagaac-3 and reverse primer VP-15 R:5- ccggaattc ttaacgccttgacttgcggg-3' (Sarathi et al., 2010). The bacteria were inactivated by the heat-killed bacteria method by immersion at $80^{\circ} \mathrm{C}$ for 5 minutes (Aonullah et al., 2016). The success of the inactivation process was checked by regrowing recombinant bacteria to validate the presence of dsRNA gene construct in bacterial plasmids by PCR technique. The inactivated bacteria carrying the pT7-VP15 gene construct were stored at $-20^{\circ} \mathrm{C}$ until the vaccine was applied.

\section{Animal testing}

A number of 150 tiger shrimp $(25.2 \pm 4.2 \mathrm{~g}$ in weight and $13.6 \pm 0.7$ $\mathrm{cm}$ in length) were collected from shrimp culture pond at Tiger Shrimp Breeding Station. The tiger shrimp were transferred to the concrete tank at the quarantine room for acclimatization for one week. The tiger shrimps were screened for the presence of WSSV by PCR to get healthy shrimp for the experiment and then maintained in three tanks with a volume of 3 tons and a density of 50 shrimp/tank during the application of treatments.

\section{Administration of oral vaccination and WSSV challenge} test

Preparation of feed containing dsRNA was carried out by referring to Puneeth et al. (2017). A total of $0.02 \mathrm{~g}$ of commercial shrimp pellet (a protein content of $30 \%$ ) was mixed with $10^{8}$ cells of inactivated bacteria, then incubated on ice for 15 minutes and then at room temperature for 30 minutes to allow absorption, before being coated with fish oil to prevent dispersion. The application of feed containing dsRNA was carried out on shrimp with the following treatment:

(A) Feed containing dsRNA and coated by fish oil.

(B) Feed without dsRNA and coated by fish oil (positive control).

(C) Feed without dsRNA and fish oil (negative control).

The shrimp were challenged with WSSV by intramuscular injection with a concentration of $50 \mu \mathrm{L} /$ shrimp (based on LC-50 in the previous study). Each treatment consisted of 4 replications divided into three replications for survival rate observation and one for immune responses sampling. The shrimp that have been vaccinated with dsRNA through feed was kept in a $250 \mathrm{~L}$ tank with a density of 10 shrimp/tank using 32 ppt seawater media. The feed was given twice a day at a dose of $3.5 \%$ of body weight for two weeks. Then the shrimp were continuously given the commercial feed with the same dose until the end of the study.

\section{Observation of survival and immune responses}

The survival rate of tiger shrimp after the challenge test was observed daily. To determine the effect of the challenge test on the immune response, hemolymph was taken before the challenge test, then on the $1^{\text {st }}, 3^{\text {rd }}$ and $5^{\text {th }}$ days post-challenge (dpc).

The observed immune responses included total haemocyte count (THC) and prophenoloxidase (proPO) activity. THC was observed by taking $0.1 \mathrm{~mL}$ of hemolymph from the second segment of the abdomen using a $1 \mathrm{~mL}$ volume syringe and a 26 gauge needle containing $0.3 \mathrm{~mL}$ of $3.8 \%$ Na-citrate anticoagulant (Braak, 2002). The haemocyte cells were observed under a microscope with a magnification of 100 times and total haemocyte cells were calculated using a formula of Braak (2002). The proPO activity was analysed based on the dopachrome formation produced by L-dihydroxyphenol alanine (L-DOPA) using a spectrophotometer. Measurement of proPO activity was performed referred to the procedure of Liu and Chen (2004).

\section{Data analysis}

The production of the VP15-dsRNA vaccine and the result of WSD detection were descriptively presented. To determine the influence of dsRNA vaccine application on the feed, the data of survival and immune response of tiger shrimp were analyzed using an analysis of variance 
(ANOVA) at a confidence level of 0.95 , following by LSD for further analysis.

\section{RESULTS AND DISCUSSION Production of VP15-dsRNA vaccine by in-vivo}

The in-vivo production of the VP15-dsRNA vaccine was successfully carried out by cloning the gene construction of pT7-VP15 to recombinant bacteria. The insert gene construct was observed by isolating VP15-dsRNA from recombinant bacterial plasmids after the heat-killed bacteria for 5 minutes (Fig 1). The result of the dsRNA vaccine showed a high level of purity (1.79-1.84) and a very clean DNA band on the agarose gel. Linacero et al. (1998) have recommended that DNA purity should be in the range of 1.8-2.0. The concentration of bacteria used a test material of dsRNA for mixing to feed was $1.5-4.17 \times 10^{10} \mathrm{CFU} / \mathrm{mL}$ as the basis for calculating the dose of application.

The result showed that the bacteria were inactive after heating at $80^{\circ} \mathrm{C}$ for 5 minutes, while the bacteria grew well normally without heating. However, the RNAi gene construct is still detected on the gel agarose. In our previous study on various heating incubation times, the gene construct of VP15 in the plasmid was not damaged by heating at $80^{\circ} \mathrm{C}$ for up to 15 minutes, even though the bacteria were inactive (dead) (Parenrengi et al., 2018).

\section{Survival rate}

The survival rate of tiger shrimp for all treatments tended to decrease until the $3^{\text {rd }} d p c$ and the $4^{\text {th }} d p c$ the dsRNA application treatment started to exhibit higher survival than both control treatments (Fig 2A). The positive and negative

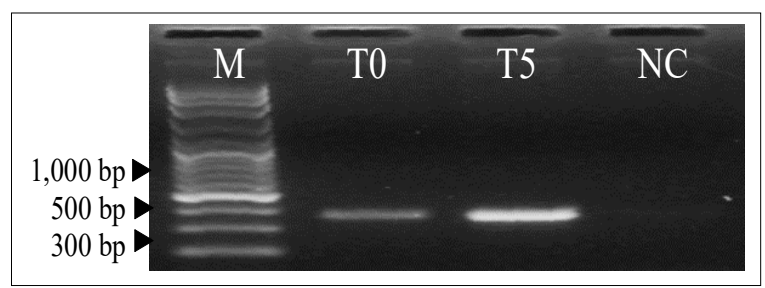

Fig 1: Electrophoresis of plasmid isolated from bacteria carrying the dsRNA VP15 vaccine. M=DNA marker, T0=without heating (control), $\mathrm{T} 5=$ heating for 5 minutes and $\mathrm{N}=$ negative control. control showed a decrease in survival up to $3.3 \%$ and $0 \%$, respectively on the $5^{\text {th }} \mathrm{dpc}$ and then total death occurred on the $6^{\text {th }} \mathrm{dpc}$. The vaccinated shrimp showed a high survival compared to the two controls, reaching $30 \%$ on the $5^{\text {th }} \mathrm{dpc}$ and relatively stable at $27.3 \%$ survival until the end of the study. The statistical analysis on the $5^{\text {th }} d p c$ showed that the use of feed containing dsRNA vaccine significantly increased $(P<0.05)$ the survival rate by $26.7 \%$ higher than the control (Fig 2B).

Survival enhancement of vaccinated shrimp was presumably because dsRNA-treated tiger shrimp could fight pathogen infection by an increased immune response system and inhibition of WSSV virulence gene expression, which causes non-pathogens. The inactivation mechanism of virulence genes has been described by Mocellin and Provenzano (2004) and Reshi et al. (2014). Previous research by Parenrengi et al., (2018) showed that the use of VP15-dsRNA increased the tiger shrimp survival (36.7\%) compared to unvaccinated shrimp (3.3\%). A study of the dsRNA VP-24 vaccine at a dose of $0.2 \mu \mathrm{g}$ showed a significant increase in survival rate in tiger shrimp by $65 \%$ compared to control (10\%) (Mulyaningrum et al., 2018). Some studies also demonstrated that the intramuscular injection and oral delivery of dsRNA can provide better protection than control groups of tiger shrimp (Puneeth et al., 2017) and our studies indicated that the application of dsRNA by injection showed a better survival response than oral administration (Mulyaningrum et al., 2018; Parenrengi et al., $2018 ; 2019)$. The shrimp survival by injected with dsRNA of VP24, VP19 and VP15 (Sarathi et al., 2010) and VP28 (Nilsen et al., 2017; Sarathi et al., 2008; Solis-Lucero et al., 2016) was significantly higher than that of control groups. The survival enhancement of tiger shrimp by $50 \%$ has also been reported by Puneeth et al. (2017) using the VP24 vaccine by a dose of $2.5 \mu \mathrm{g} / \mathrm{g}$ of body weight.

\section{Total haemocyte count}

The resistance pattern of tiger shrimp through THC observation showed a decreasing trend on the $1^{\text {st }} \mathrm{dpc}$ and subsequently increased with the longer exposure to WSSV (Fig 3). The decrease in THC is generally caused by the migration of haemocytes from the body's circulatory system to the tissues due to many infected cells (Yeh et al., 2009).

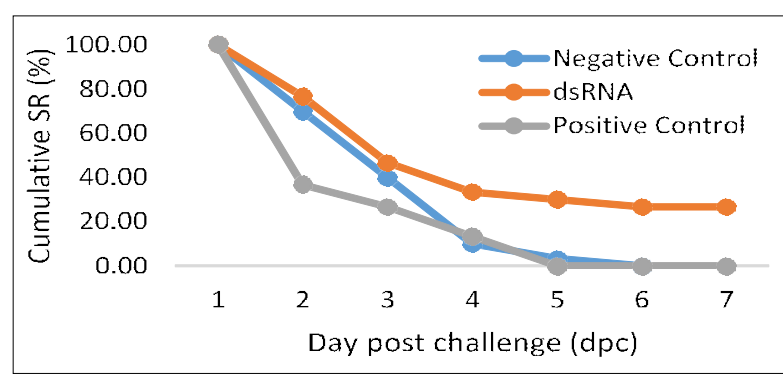

(A)

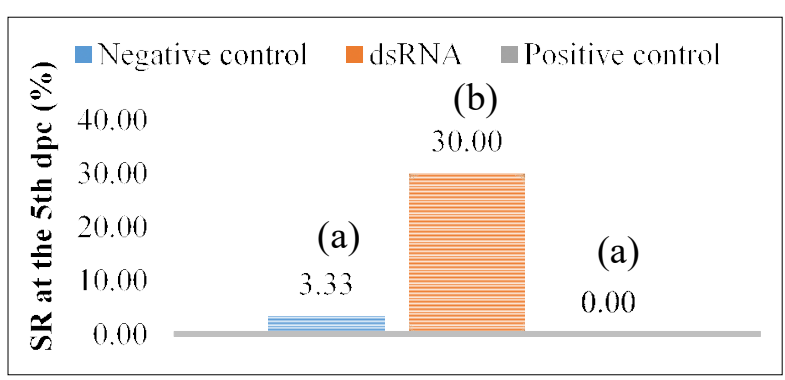

(B)

Fig 2: The cumulative survival rate of tiger shrimp fed with dsRNA VP15 by oral vaccination after challenge test (A) and the survival average on the $5^{\text {th }} d p c(B)$. The survival rate of the $5^{\text {th }} d p c$ with different letters were significantly different $(P<0.05)$. 
The result showed that the feed treatment containing dsRNA was the highest average of THC $\left(1.98 \times 10^{7}\right.$ cells $\left./ \mathrm{mL}\right)$, then negative control $\left(1.31 \times 10^{7}\right.$ cells $\left./ \mathrm{mL}\right)$ and positive control $\left(1.09 \times 10^{7}\right.$ cells $\left./ \mathrm{mL}\right)$. The analysis of variance showed that the application of the dsRNA VP15 vaccine had a significant effect $(P<0.05)$ on the amount of THC. The following further test suggested that the THC of vaccinated shrimp was significantly different from the other treatments.

Mulyaningrum et al. (2018) reported that applying the dsRNA VP-24 vaccine by muscular injection had a significant effect on the amount of THC in tiger shrimp haemocytes, where the optimal dose was $0.2 \mu \mathrm{g} / \mathrm{shrimp}$ with a total THC of $1.55 \times 10^{7}$ cells $/ \mathrm{mL}$. The increase in the number of haemocyte cells in the shrimp body plays an important role in inhibiting or destroying pathogens that enter the shrimp body. In crustaceans, there are three main types of blood cells: granular cells, semi-granular cells and hyaline cells, which play a role in immunity and defense against infection (Rowley and Pope, 2012; Wentao et al., 2017). As with vaccines, giving immunostimulants to shrimp that are carried out continuously can regulate and maintain the immune system in optimal conditions until the administration stops (Basavaraja, 2013; Jane et al., 2015).

\section{Prophenoloxidase activity}

The results showed that the proPO activity tended to decrease with the length of time the WSSV exposure and had not exhibited the effect of dsRNA application until the $3^{\text {rd }}$ dpc (Fig 4). This is supposed to be due to a powerful attack of WSSV infection. The immune response, especially the proPO parameter, is suppressed, resulting in decreased activity. The interesting point on the $5^{\text {th }} \mathrm{dpc}$ that the ProPO activity in vaccinated tiger shrimp showed higher values than both controls. However, the statistical analysis indicated that the average value of proPO activity was not significantly different $(P>0.05)$ among treatments. This is presumably due to a strong infection attack and also shows that the immune response induction pathway of proPO was not as high as the direct RNA inhibition (interference) pathway.

In contrast, Parenrengi et al. (2019) reported that dsRNA vaccine had a significant effect on the proPO activity of tiger shrimp, where the highest proPO activity was obtained in the in-vivo VP15 dsRNA and subsequently invitro and the lowest in control (without dsRNA). This study also revealed that proPO activity increased the longer test animals were exposed to WSSV. The same finding was reported in the application of dsRNA VP24, where proPO activity of tiger shrimp increased from 24 hours to 72 hours after being challenged with WSSV (Mulyaningrum et al., 2018). Meanwhile, Paria et al. (2013) reported that the WSSV challenge test on the dsRNA VP28 test did not provide a significant change in the proPO gene expression of tiger shrimp up to 24 hours. However, there was an increase in expression up to threefold at 48 hours after injection.

The proPO activation cascade in the shrimp plays an important role of immune system to respond quickly to pathogen infection (Amparyup et al., 2013). Tassanakajon et al. (2013) explained that among the various types of humoral immune responses, one of the most effective invertebrate immune techniques against foreign particles is cellular melanotic encapsulation or melanisation which is carried out by activating proPO system involving PO

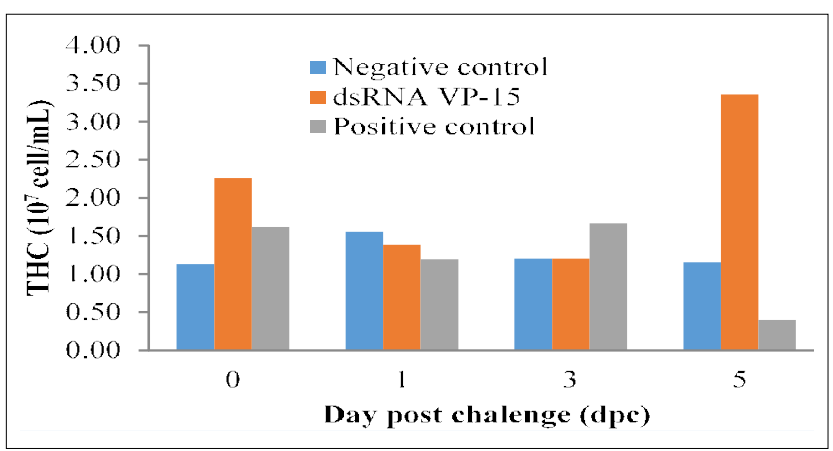

Fig 3: The THC of tiger shrimp for initial day and the $1^{\text {st }}, 3^{\text {rd }}$ and $5^{\text {th }} \mathrm{dpc}$.

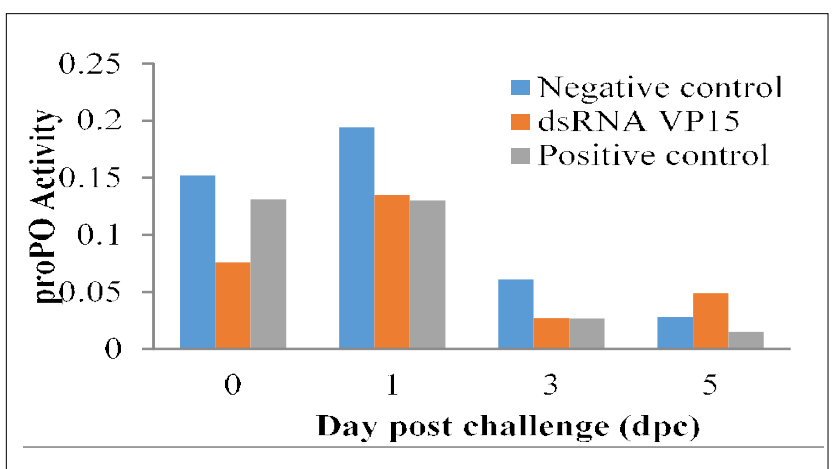

Fig 4: The proPO value of tiger shrimp at initial day and the $1^{\text {st }}$, $3^{\text {rd }}$ and $5^{\text {th }} \mathrm{dpc}$.

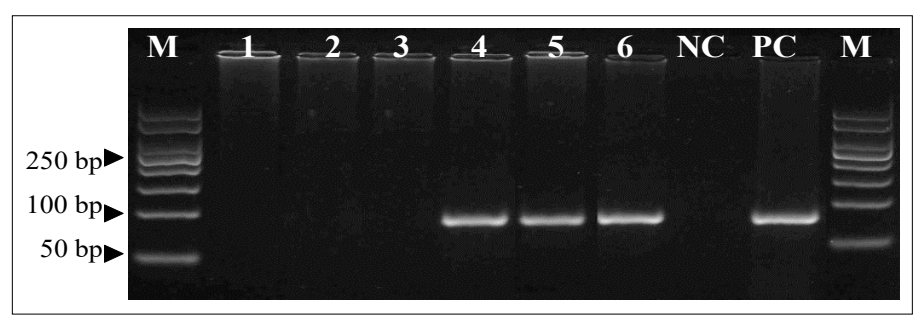

Fig 5: Verification of WSD on tiger shrimp before and after the challenge test with WSSV. M=DNA marker, 1-3=shrimp samples before challenge test, $4-6=$ dead shrimp samples, $N C=$ negative control and $P C=$ positive control. 
Application of dsRNA VP15-WSSV by Oral Vaccination to Increase Survival Rate and Response Immunes of Tiger Shrimp..

enzymes. A decrease in the activity of the proPo system can lead to phagocytosis failure and cause tissue damage (Amparyup et al., 2013).

\section{WSD detection}

The disease detection results showed that the tiger shrimp used before the challenge test were negative of WSSV infection or free from WSD, while the dead shrimp after the challenge test was also observed to verify of mortality due to WSSV attack (Fig 5). The presence of approximately $93 \mathrm{bp}$ DNA band on the gel agarose was an indicator of positive WSSV infection. The evidence of shrimp mortality due to WSSV infection has also been reported by Escobedo-Bonilla et al. (2015), that the dead shrimp after the challenge test were confirmed positive for WSSV, while the shrimp that were still alive showed no clinical signs of infection and all were negative for WSSV by PCR assays.

\section{CONCLUSION}

The VP15-dsRNA vaccine was successfully produced invivo and applied to commercial feed for oral administration. The use of the dsRNA vaccine in oral delivery increased survival and immune response of $\mathrm{THC}$, but no differences in proPO activity were not shown. The direct effect of the dsRNA vaccine on survival may be greater than the induction of shrimp immune response. These results provided important information on developing a strategy of RNAibased therapeutics in shrimp aquaculture against WSD.

\section{ACKNOWLEDGMENT}

This research was supported by the Indonesian Government through DIPA-2019 of RIBAFE). The authors would like to thank the researchers and technicians of RIBAFE for their assistance during the study and in completing the manuscript. I would also declare that we (Andi Parenrengi, Andi Tenriulo and Emma Suryati) are the main contributors and the other authors as co-contributors.

\section{REFERENCES}

Amparyup, P., Charoensapsri, W., Tassanakajon, A. (2013). Prophenoloxidase system and its role in shrimp immune responses against major pathogens. Fish and Shellfish Immunology. 34(4): 990-1001. DOI:10.1016/j.fsi.2012.08.019.

Aonullah, A.A., Nuryati, S., Alimuddin, Murtini, S. (2016). Efficacy of koi herpesvirus DNA vaccine administration by immersion method on Cyprinus carpio field scale culture. Aquaculture Research. 48(6): 2655-2662. DOI: 10.1111/ are.13097.

Basavaraja, N. (2013). Efficacy of macrogard (an immunostimulant) on growth and survival in shrimps and carps. Indian Journal of Animal Research. 47(5):443-448.

Boonyakida, J., Xu, J., Satoh, J., Nakanishi, T., Mekata, T., Kato, T., Park, E.Y. (2020). Antigenic properties of VP15 from white spot syndrome virus in kuruma shrimp Marsupenaeus japonicus. Fish and Shellfish Immunology.101: 152-158. DOI:10.1016/j.fsi.2020.03.061.
Braak, K. (2002). Haemocytic Defence in Black Tiger Shrimp (Penaeus monodon). Wageningen University.

Escobedo-Bonilla, C.M., Vega-Peña, S., Mejía-Ruiz, C.H. (2015). Efficacy of double-stranded RNA against white spot syndrome virus (WSSV) non-structural (orf89, wsv191) and structural (vp28, vp26) genes in the Pacific white shrimp Litopenaeus vannamei. Journal of King Saud University-Science. 27(2): 182-188. DOI:10.1016/ j.jksus.2014.11.004.

Feng, S., Wang, C., Hu, S., Wu, Q., Li, A. (2017). Recent progress in the development of white spot syndrome virus vaccines for protecting shrimp against viral infection. Archives of Virology. 162(10): 2923-2936. DOI:10.1007/s00705-0173450-x.

Itsathitphaisarn, O., Thitamadee, S., Weerachatyanukul, W., Sritunyalucksana, K. (2016). Potential of RNAi applications to control viral diseases of farmed shrimp. Journal of Invertebrate Pathology. 147: 76-85. DOI:10.1016/j.jip.2016.11.006.

Jane, M., Amar, A., Amar, E. (2015). Use of immunostimulants in shrimp culture: An update. Biotechnological Advances in Shrimp Health Management in The Philipinnes. C. Marlowe., C.M. Beth., Bacano-Maningas., F.F. Fagutao. Visayas, Miagao, Iloilo, Philippines: 45-71. https:// www.researchgate.net/publication/280656134.

Kiataramgul, A., Maneenin, S., Purton, S., Areechon, N., Hirono, I., Brocklehurst, T.W., Unajak, S. (2020). An oral delivery system for controlling white spot syndrome virus infection in shrimp using transgenic microalgae. Aquaculture. 521. DOI:10.1016/j.aquaculture.2020.735022.

Linacero, R., Rueda, J., Vazquez, A. (1998). Quantification of DNA. In: Molecular Tools for Screening Biodiversity: Plants and Animals. Springer Netherlands. (p. 528).

Liu, C.H. and Chen, J.C. (2004). Effect of ammonia on the immune response of white shrimp Litopenaeus vannamei and its susceptibility to Vibrio alginolyticus. Fish and Shellfish Immunology, 16(3): 321-334. DOI:10.1016/S10504648(03)00113-X.

Mocellin, S. and Provenzano, M. (2004). RNA interference: Learning gene knock-down from cell physiology. Journal of Translational Medicine. 2(39): 1-6. DOI:10.1186/14795876-2-39.

Mulyaningrum, S.R.H., Parenrengi, A., Tampangallo, B.R., Trismawanti, I. (2018). Respons imun udang windu Penaeus monodon terhadap vaksin dsRNA VP-24 pada dosis berbeda. Jurnal Riset Akuakultur. 13(1):77-84. DOI:10.15578/jra.13.1.2018.77-84.

Nilsen, P., Karlsen, M., Sritunyalucksana, K., Thitamadee, S. (2017). White spot syndrome virus VP28 specific doublestranded RNA provides protection through a highly focused siRNA population. Scientific Reports. 7(1): 1-14. DOI: 10.1038/s41598-017-01181-w.

Parenrengi, A., Mulyaningrum, S.R.H., Tenriulo, A., Nawang, A. (2018). Gen penyandi viral protein 15 (VP-15) white spot syndrome virus (WSSV) dan aplikasinya sebagai vaksin rekombinan pada udang windu. Jurnal Riset Akuakultur. 13(1): 57-65. DOI:10.15578/jra.13.1.2018.57-65. 
Parenrengi, A., Alimuddin, A., Tenriulo, A. (2017). Characteristics of viral protein, VP-15, of white spot syndrome virus isolated from infected tiger shrimp Penaeus monodon (Fabricius, 1798). Indonesian Aquaculture Journal. 12(2): 67-75. DOI:10.15578/iaj.12.2.2017.67-75.

Parenrengi, A., Tenriulo, A., Mulyaningrum, S.R.H., Lante, S., Nawang, A. (2019). Pengaruh aplikasi dsRNA VP-15 in vitro dan in-vivo terhadap sintasan dan respons imun udang windu Penaeus monodon. Jurnal Riset Akuakultur. 14(4): 213-223. DOI: 10.15578/jra.14.4.2019.213-223.

Paria, A., Greeshma, S.S., Chaudhari, A., Makesh, M., Purushothaman, C.S., Rajendran, K.V. (2013). Nonspecific effect of double-stranded (ds) RNA on prophenoloxidase (proPO) expression in Penaeus monodon. Applied Biochemistry and Biotechnology. 169: 281-289. DOI:10.1007/s12010012-9964-5.

Puneeth, T.G., Akhila, D.S., Dechamma, M.M., Shreeharsha, J.M., Shivakumar, S.K., Venugopal, M.N. (2017). Comparative efficacy of dsRNA VP24, VP26, RR1 and WSV477 gene against WSSV Infection in Penaeus monodon. International Journal of Current Microbiology and Applied Sciences. 6(2): 665-674. DOI:10.20546/ijcmas.2017. 602.075.

Reshi, M.L., Wu, J.L., Wang, H.V., Hong, J.R. (2014). RNA interference technology used for the study of aquatic virus infections. Fish and Shellfish Immunology. 40(1): 14-23. DOI: 10.1016/j.fsi.2014.06.008.

Rowley, A.F. and Pope, E.C. (2012). Vaccines and crustacean aquaculture-A mechanistic exploration. Aquaculture, 334-337:1-11. DOI:10.1016/j.aquaculture.2011.12.011.

Sarathi, M., Simon, M.C., Ahmed, V.P.I., Kumar, S.R. and Hameed, A.S.S. (2008). Silencing VP28 gene of white spot syndrome virus of shrimp by bacterially expressed dsRNA. Marine Biotechnology. 10(2):198-206. DOI:10.1007/s10126-007-9052-y.

Sarathi, M., Simon, M.C., Venkatesan, C., Thomas, J., Ravi, M., Madan, N., Thiyagarajan, S., Sahul Hameed, A.S. (2010). Efficacy of bacterially expressed dsRNA specific to different structural genes of white spot syndrome virus (WSSV) in protection of shrimp from WSSV infection. Journal of Fish Diseases. 33(7): 603-607. DOI:10.1111/ j.1365-2761.2010.01157.x.

Solis-Lucero, G., Manoutcharian, K., Hernández-López, J., Ascencio, F. (2016). Injected phage-displayed-VP28 vaccine reduces shrimp Litopenaeus vannamei mortality by white spot syndrome virus infection. Fish and Shellfish Immunology. 55:401-406. DOI:10.1016/j.fsi.2016.05.027.

Tassanakajon, A., Somboonwiwat, K., Supungul, P., Tang, S. (2013). Discovery of immune molecules and their crucial functions in shrimp immunity. Fish and Shellfish Immunology. 34(4): 954-967. DOI:10.1016/j.fsi.2012.09.021.

Uma, A., Parthiban, M., Chandran, N.D.J., Thiyagarajan, B., Arasi, P.K., Koteeswaran, A. (2005). Usefulness of nested polymerase chain reaction in detection of monodon baculovirus in shrimp seeds. Indian Journal of Animal Research. 39(2): 111-114.

Van Hulten, M.C.W., Reijns, M., Vermeesch, A.M.G., Zandbergen, F., Vlak, J.M. (2002). Identification of VP19 and VP15 of white spot syndrome virus (WSSV) and glycosylation status of the WSSV major structural proteins. Journal of General Virology. 83(1): 257-265. DOI:10.1099/00221317-83-1-257.

Van Hulten, M.C.W., Witteveldt, J., Snippe, M., Vlak, J.M. (2001). White spot syndrome virus envelope protein VP28 is involved in the systemic infection of shrimp. Virology. 285(2): 228-233. DOI:10.1006/viro.2001.0928.

Wentao, Z., Wen, L., Yunlong, Z., Danli, W., Zhongxiang, M., Getao, S. (2017). Ultrastructural and immunocytochemical analysis of circulating hemocytes from Cherax quadricarinatus (Von Martens, 1868). Indian Journal of Animal Research. 51(1): 129-134. DOI:10.18805/ ijar.v0iOF.6823.

Witteveldt, J., Vermeesch, A.M.G., Langenhof, M., de Lang, A., Vlak, J. M., Van Hulten, M.C.W. (2005). Nucleocapsid protein VP15 is the basic DNA binding protein of white spot syndrome virus of shrimp. Archives of Virology. 150(6): 1121-1133. DOI:10.1007/s00705-004-0483-8.

Xing, Y. and Shi, Z. (2011). Nucleocapsid protein VP15 of white spot syndrome virus colocalizes with the nucleolar proteins nucleolin and fibrillarin. Canadian Journal of Microbiology. 57(9): 759-764. DOI:https://doi.org/10.1139/ w11-061.

Yeh, S.P., Chen, Y.N., Hsieh, S.L., Cheng, W., Liu, C.H. (2009). Immune response of white shrimp, Litopenaeus vannamei, after a concurrent infection with white spot syndrome virus and infectious hypodermal and hematopoietic necrosis virus. Fish and Shellfish Immunology. 26(4): 582-588. DOI:10.1016/j.fsi.2008.09.010. 